\title{
Evaluating anti $\beta-2$ glycoprotein as rapid thromboembolic marker among HCV patients in Egypt
}

\author{
Elkhouly EH ${ }^{1}$, Morsi MG ${ }^{2, *}$, Hamed NA ${ }^{3}$, Soliman $\mathrm{AA}^{3}$, Hanafi $\mathrm{NF}^{2}$ \\ ${ }^{1}$ Tropical, Faculty of Medicine, University of Alexandria, Egypt \\ ${ }^{2}$ Medical Microbiology\& Immunology, Faculty of Medicine, University of Alexandria, Egypt \\ ${ }^{3}$ Internal Medicine (Hematology unit), Faculty of Medicine, University of Alexandria, Egypt
}

Email address:

morsirg@yahoo.com (Morsi MG)

To cite this article:

Elkhouly EH, Morsi MG, Hamed NA, Soliman AA, Hanafi NF. Evaluating Anti $\beta-2$ Glycoprotein as Rapid Thromboembolic Marker Among HCV Patients in Egypt, American Journal of Life Sciences. Vol. 1, No. 1, 2013, pp. 1-5. doi: 10.11648/j.ajls.20130101.11

\begin{abstract}
Although antiphospholipid (APL) antibodies are still not clearly known, yet they have association with thromboembolic events associated with hepatitis $\mathrm{C}$ virus $(\mathrm{HCV})$ infection. Moreover, high percent of $\mathrm{HCV}$ infections and thromboembolic risk was associated among thalassemic patients. So our aim was to screen and evaluate the significance of ACL and anti $\beta-2$ glycoprotein seroprevelance among patients receiving repeated blood transfusions, in patients with infectious diseases as chronic HCV disorders, and in healthy subjects resident in Egypt, a tropical country endemic for hepatitis and to evaluate these tests as rapid markers for early detection of thrombotic HCV infection among chronic liver disorders and cases receiving repeated blood transfusion aiming at early anticoagulant therapy.The study was carried out on 70 patients attending Tropical, Hepatology and Hematology departments in Alexandria Main University Hospital, Egypt as well as 30 healthy subjects served as controls. Group I; 35 chronic liver disorders as chronic HCV, cirrhosis and Hepatocellular carcinoma(HCC) diagnosed by clinical, ultrasound and histopathology. Group II ; 35 receiving repeated blood transfusion as thalassemia. Group III; healthy relatives -ve for HCV antibody of matched age and sex. Both markers were screened by commercial enzyme immunosorbant assays (ELISA) (Calbiotech,USA). Our results revealed that patients with chronic HCV infection had higher anticardiolipin (ACL) IgG and antibeta2GP1 IgG compared to healthy controls. (26.6\%) 8 patients from group I had high ACL IgG compared to 6 patients (20\%) of group II .The study also revealed that anti $\beta$-2 glycoprotein IgG was higher among Group I and II compared to controls group III. Group I was higher than group II. Three patients $(10 \%)$ of group I had high anti $\beta 2$ glycoprotein 1 IgG compared to 2 patients $(6.6 \%)$ among group II . We can conclude that anticardiolipin (ACL)alone is not diagnostic for thrombosis \& it should be accompanied with antibeta( $\beta$ )2glycoprotein-1 in serum of the same patient to be considered a cause of thrombosis in chronic HCV patients. So, ACL alone can not be considered rapid marker of thrombosis in HCV positive patients. We recommend anti $\beta 2$ glycoprotein as a biomarker predicting thrombotic HCV infection.
\end{abstract}

Keywords: Anti $\beta 2$ glycoprotein , ACL, ELISA, HCV, RT-PCR, Thromboembolic Rapid Markers

\section{Introduction}

Antiphospholipids antibodies (APL) are circulating immunoglobulins that bind to negatively charged phospholipid and promote abnormal coagulation that predisposes to arterial or venous thrombosis. Anticardiolipin (ACL) is the most commonly investigated APL in relation to stroke and transient ischemic attacks. Although several well conducted studies have demonstrated the association of ACL with a prothrombotic state and stroke, (1) the pathogenesis and the risk prediction in ischemic stroke are still debatable $(2,3)$.
Several reports have clearly shown that several viral, bacterial, and parasitic infections are associated with generation of APL(4-8).

A high prevelance of APL was observed in inhabitants of regions such as tropical Africa, where there is high endemicity of infectious diseases(4-6). Although these infections can induce APL expression, the increase in antibodies was not accompanied by manifestations of the antiphospholipid syndrome (APS) such as thrombosis(9).

People with APS make antibody to beta- 2 glycoprotein I. Beta-2 glycoprotein I binds to phospholipids that " flipped " to outside of cell. 
Elevated levels of ACL were found by several investigators in $\mathrm{HCV}$ patients and these were all beta2 glycoprotein I ( $\beta 2 \mathrm{GPI})$-independent $(10)$.

Although the precise nature of APL is still not known, yet reported association with thromboembolic events and hepatitis $\mathrm{C}$ virus (HCV) infection was issued by some researchers. Moreover, high $\mathrm{HCV}$ infection and thrombotic risk was described among thalassemic patients $(11,12)$.

Hepatitis $\mathrm{C}$ virus ( $\mathrm{HCV}$ ) was recognized as a major threat to the whole globe. It has been estimated that 170 million people were infected worldwide, most of them chronically infected and at risk for liver cirrhosis and hepatocellular carcinoma (HCC).

The highest prevelance was among Egyptians; 10 - 20\% of the population were chronically infected, some with HCC and others were cirrhotic $(13,14)$.

Our aim was to screen and evaluate the significance of ACL and anti $\beta-2$ glycoprotein among patients receiving repeated blood transfusions like thalassemia, in patients with infectious diseases as chronic HCV disorders, and in healthy subjects resident in Egypt, a tropical country endemic for hepatitis.

Evaluating these tests as rapid markers for early detection of thrombotic HCV infection among chronic liver disorders and cases receiving repeated blood transfusion will aid clinicians at early anticoagulant therapy preventing thromboembolic menifestations.

\section{Subiects and Methods}

The current research was carried out on 70 patients attending Hematology, Hepatology and Tropical Departments, Alexandria Main University Hospital, Egypt as well as 30 healthy subjects served as controls.

An informed consent from all enrollees was taken and approved by our ethical committee.

Case selection was done according to the following criteria: Male or female aged from 20-60 years, HCV antibody and PCR (polymerase chain reaction ) positive.

Group I ; 35 receiving repeated blood transfusion (thalassemia major),

Group II ; 35 chronic liver disorders as chronic HCV, cirrhosis and HCC diagnosed by histopathology and Group III; healthy relatives -ve for HCV antibody of matched age and sex. All enrollees were subjected to: history taking ( Personal- medical- surgical and therapeutic), blood samples were drawn for laboratory investigations $(6,8)$;

Estimating both ACL( $\operatorname{IgM}$ and $\mathrm{IgG}$ ) and anti beta 2 glycoprotein(Antiß2GPI) in sera by commercial enzyme linked immunosorbent assay ( ELISA), Calbiotech,USA.

Principle of ELISA; It was an indirect solid phase enzyme linked immunosorbant assay for the quantitative measurement of $\mathrm{IgG}$ and $\operatorname{IgM}$ against cardiolipin and beta2 glycoprotein (Antiß2GPI) in human sera .We followed the manufacturer instructions which was as follows:

Highly purified antigen as cardiolipin or $\beta 2$ glycoprotein was bound to microwells. Antibodies to these antigens were bound to microwells. Several washing of microwells removed unbound serum antibodies. Then we added antihuman IgG and IgM conjugated to horseradish peroxidase which bound to patient antibodies forming a conjugate/antibody/antigen complex. Washing microwells several times removed the unbound conjugate. Finally we added an enzyme substrate which in the presence of bound conjugate was hydrolyzed to form a blue color. The addition of an acid stopped the reaction forming a yellow end-product. The intensity of this yellow color was measured photometrically by an ELISA reader at $450 \mathrm{~nm}$ (Behring,Germany). The amount of colour was directly proportional to the concentration of $\mathrm{IgG}$ and $\mathrm{IgM}$ antibodies present in the original sample.

Statistical tests: was performed using SSPS version 15 Microsoft, USA.

\section{Results}

The current study revealed the following data:

Table (1) illustrates ACL and Antiß2GPI \% among the three studied groups, ACL ranged between 16.30-24.50, $12.10-20.0$ and $4.30-11.70$ with the mean of $20.01 \pm 2.57$, $16.61 \pm 2.53$ and $8.65 \pm 2.24$ for the three studied groups. The first 2 groups (cases) revealed statistically higher values than group III (controls), also group I values were higher than group II. $(\mathrm{P}=0.0001)$.

Table 1. Comparing both markers (ACL and Antiß2GPI) among studied groups.

\begin{tabular}{|c|c|c|c|c|c|}
\hline & & Mean & S.D. & Min. & Max. \\
\hline \multirow{3}{*}{$\begin{array}{l}\text { Anticardiolipin } \\
\text { antibodies } \\
\text { (ACL) }\end{array}$} & Group I (no.35) & 20.0133 & 2.57665 & 16.30 & 24.50 \\
\hline & Group II (no.35) & 16.6133 & 2.53578 & 12.10 & 20.00 \\
\hline & $\begin{array}{l}\text { Control } \\
\text { (no.30) }\end{array}$ & 8.6500 & 2.24818 & 4.30 & 11.70 \\
\hline $\mathrm{F}$ & & 168.923 & & & \\
\hline $\mathrm{p}$ & & $.0001 *$ & & & \\
\hline \multirow{3}{*}{$\begin{array}{l}\text { Anti } \beta-2 \\
\text { glycoprotein }\end{array}$} & Group I & 5.6200 & 1.76545 & 2.50 & 9.00 \\
\hline & Group II & 3.5933 & 1.78614 & 1.20 & 7.00 \\
\hline & Control group & 2.3867 & .95076 & .60 & 4.00 \\
\hline $\mathrm{F}$ & & 33.3 & & & \\
\hline $\mathrm{p}$ & & $.0001 *$ & & & \\
\hline
\end{tabular}

$* P$ is significant $\leq 0.05$.

While Antiß2GPI \% among the three studied groups ranged between $2.50-9.0,1.20-7.0$ and $0.60-4.0$ with the mean of $5.62 \pm 1.7,3.59 \pm 1.78$ and $2.38 \pm 0.95$ for the 3 studied groups. Cases; groups I \& II had values statistically higher than group III (control group), meanwhile group I values were higher than group II. $(\mathrm{P}=0.0001)$.

Correlations between different studied parameters were 
presented in table (2) showed correlations between different studied parameters, it shows that, there was positive significant correlation between anti $\beta-2$ GP and ACL antibodies $(\mathrm{P}=0.0001)$, while there was no significant correlation between HCV load done quantitatively by real time polymerase chain reaction (RT-PCR) and both ACL antibodies and anti $\beta-2$ GP. $\quad(\mathrm{P}=0.305$ and 0.649 respectively).

Table 2. Correlations between different studied parameters.

\begin{tabular}{llll}
\hline & & $\begin{array}{l}\text { Anticardiolipin Anti } \beta-2 \\
\text { Antibodies(ACL)Glycoprotein(GP) }\end{array}$ \\
\hline $\begin{array}{l}\text { Anti } \beta-2 \\
\text { glycoprotein }\end{array}$ & Pearson Correlation & $.531\left(^{*}\right)$ & \\
& Sig. (2-tailed) & .0001 & -.128 \\
HCV by & Pearson Correlation & .284 & .649 \\
RT-PCR & Sig. (2-tailed) & .305 & .040 \\
\hline
\end{tabular}

* Correlation is significant at the 0.01 level (2-tailed).

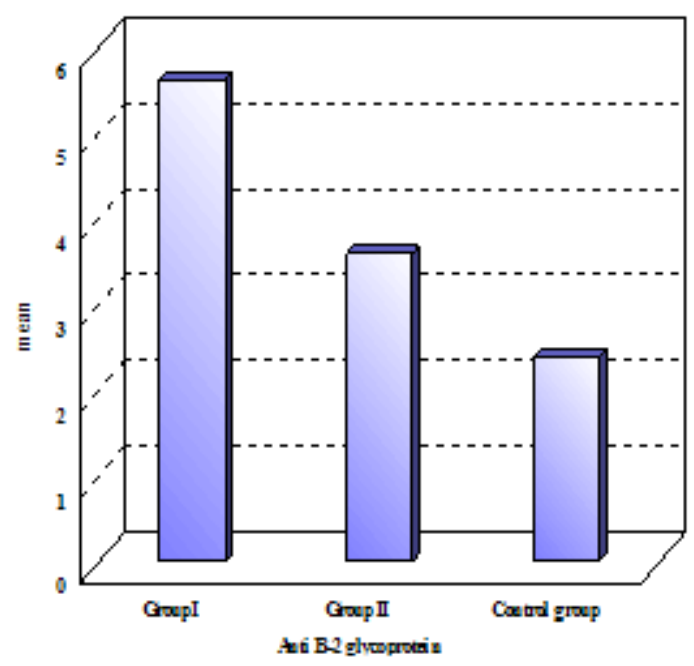

Figure 1. Comparing anti $\beta 2 G P 1$ among the three studied groups.

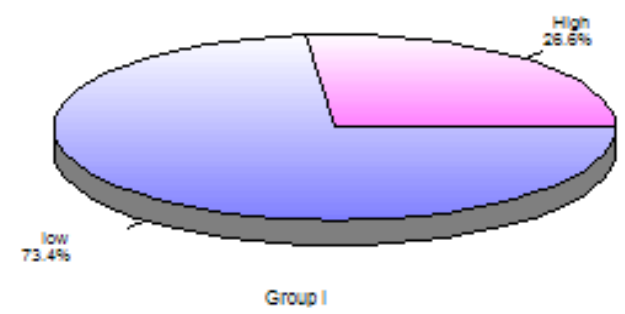

Figure 2. A pie chart for ACL \%among group I; $26.6 \%$ were high and $73.4 \%$ low.

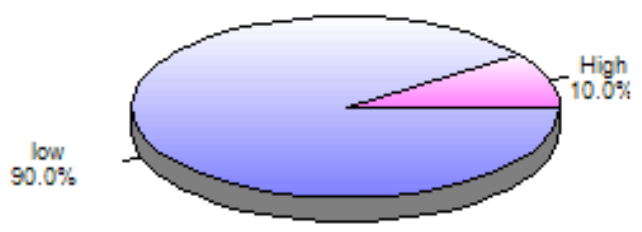

Group I

Figure 3. A pie chart of anti $\beta 2 G P 1 \%$ among group I; $10 \%$ were high and $90 \%$ low.

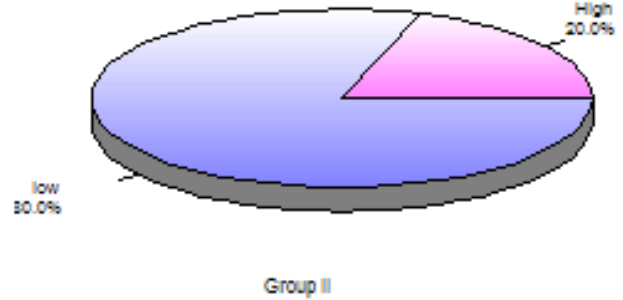

Figure 4. A pie chart of ACL\% among group II,; $20 \%$ were high and $80 \%$ low.

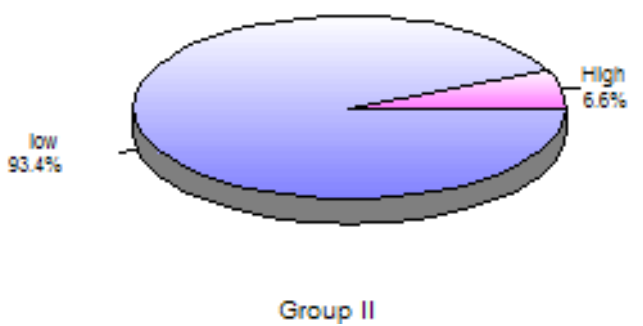

Figure 5. A pie chart of antiß2-GP1\% among group II; $6.6 \%$ high and $93.4 \%$ low.

\section{Discussion}

Hepatitis $\mathrm{C}$ is a viral infection transmitted parentally by the hepatitis $\mathrm{C}$ virus (HCV), which has six major genotypes that infect human cells, including hepatocytes, B lymphocytes, dendritic cells, monocytes, and epithelial cells $(15,16)$. Millions of people in the world are infected with this virus(17).

Infection with HCV include: i) persistence of the virus, which may cause cirrhosis and hepatocellular carcinoma and ii) autoimmunity, which is mainly represented by cryoglobulinemia and production of non-organ-specific autoantibodies, including APL autoantibodies(18-20).

APL antibodies are a group of immunoglobulins that binds to epitopes of proteins complexed with anionic phospholipids or epitopes of anionic phospholipids. Pathogenic antiphospholipid antibodies are immunoglobulins that react with proteins of the coagulation system such as 32 -glycoprotein I (ß2GPI) or prothrombin, causing a coagulation disorder known as antiphospholipid syndrome.

$\mathrm{HCV}$ persistence evokes several autoantibodies and concomitant autoimmune disorders. Autoantibodies such as non-organ-specific and liver-specific have been demonstrated in sera of patients with HCV-related chronic liver disease (CLD).

Possible mechanisms for these autoantibodies are Molecular mimicry between self proteins and HCV polyprotein, and polyclonal $\mathrm{B}$ cell activation by chronic HCV infection.

Some of these autoantibodies are tightly associated with concurrent autoimmune diseases, and others are closely associated with human leucocyte antigen (HLA).

Our results revealed that chronic $\mathrm{HCV}$ patients had significantly higher serum levels of ACL IgG and antibeta2GP1 IGg compared to healthy controls. 
Comparison between the three studied groups for ACL antibodies demonstrated that Groups I and II revealed values statistically higher than controls, also group I showed values statistically higher than group II.

The study revealed that $(26.6 \%) 8$ patients from group I have high serum anticardiolipin IgG while 6 patients $(20 \%)$ of group II have high anticardiolipin IgG. Also 3 patients $(10 \%)$ of group II have high serum anticardiolipin IgG while 2 patients $(6.6 \%)$ have high serum anti beta2glycoprotein $1 \mathrm{IgG}$.

The increased ACL levels among HCV patients in the present study were similar to other investigators done elsewhere $(21,22)$. The elevated ACL levels may cause recurrent venous or arterial thrombosis by binding to negatively charged phospholipids of the cell membrane. Its clinical significance was not settled. While some studies, including the present one, suggest the absence of thrombosis, some others indicate the occurrence of thrombosis among viral infections $(23,24)$.

The presence of ACL among viral or other infections might be induced by disturbances in the regulation of cellular and humoral immunity, which were the consequence of infectious diseases(15). In patients with chronic viral hepatitis, induction of neoantigens may provoke antibody formation by disrupting liver cell membrane(25). Moreover, viruses stimulate apoptosis this may lead to redistribution of plasma membrane phospholipids and their over expression on the apoptotic cell membrane surfaces resulting in ACL formation(22).

The present study also showed that serum levels of antibeta2GPI antibody increased among viral hepatitis patients. Such a finding was in agreement with previous reports examining the levels of the antibody in various viral infections. Viral infections were believed to induce a lower antibeta2GPI than APS or other autoimmune diseases $(26,27)$.

Beta2GPI is a single chain glycoprotein with amino acid residues arranged in five homologous domains called Sushi domains. It was suggested that ACL and antibeta2GPI antibodies recognize neo epitopes on Sushi-4 domain induced after binding of antibeta2GPI antibody to the lipid surface(28-30).

The current study also illustrated that anti $\beta-2$ glycoprotein ranged between 2.50-9.0, 1.20-7.0 and 0.604.0 with the mean of $5.62 \pm 1.7,3.59 \pm 1.78$ and $2.38 \pm 0.95$ for the three studied groups. Cases revealed higher values than controls, also group I have values statistically higher than group II. $(\mathrm{P}=0.0001)$.

Correlations between different studied parameters were presented in table (3) it showed that, there was significant positive correlation between anti $\beta$-2 glycoprotein and ACL antibodies $(\mathrm{P}=0.0001)$, while there were no statistical significant correlation between HCV positive by RT-PCR and each of ACL antibodies and anti B-2 glycoprotein. $(\mathrm{P}=0.305$ and 0.649 respectively).

Comparison between the negative and the positive HCV cases(by PCR) regarding ACL and anti B-2 glycoprotein antibodies was done to show if HCV viraemic level of the patient could affect their levels. It showed that Anticardiolipin antibodies ranged between 16.3-24.5 and 16.3-24.4 with the mean of $19.95 \pm 2.60$ and 20.07 \pm 2.64 for positive and negative HCV by PCR respectively. While there was statistical significant difference among anti $\beta-2$ glycoprotein compared to controls. Our results were similar to those done elsewhere(31-32).

No one of our studied patients had history of arterial or venous thrombosis. Also no one had high level of both ACL and Antibeta2GP1 together.

To conclude, some patients with viral hepatitis infections may produce ACL and or antibeta 2 glycoprotein as an epiphenomenon of the infectious diseases. Such patients may not show clinical signs of venous or arterial thrombosis.

Thus we can conclude that antibeta2GPI antibody may be considered a determinant factor in the production of thromboembolic manifestation in hepatitis $\mathrm{C}$ associated ACL and we recommend it as rapid biomarker to guide clinicians for early anticoagulant to prevent thromboembolic manifestations.

\section{References}

[1] Terashi H, Uchiyama S, Hashimoto S, Miyazaki K, Tsutsumi Y\& Yamazak M . Clinical characteristics of stroke patient with antiphopholipids antibodies. Cerebrovasc Dis 2005; 19: 384-390.

[2] Ginsburg KS, Liang MH, Newcomer L, Goldhaber SZ, Schur PH \& Hennekens $\mathrm{CH}$. Anticardiolipin antibodies and the risk for ischemic stroke and venous thrombosis. Ann Intern Med 1992; 117: 997-1002.

[3] Ahmed E, Birgitta S, Trifunovic J, Weinehall L, Hallmans G \& Lefvert AK. Anticardiolipin antibodies are not an independent risk factor for stroke. An incident case-referent study nested within the MONICA and Vksterbotten Cohort Project. Stroke 2000; 31: 1289-1293.

[4] Adebajo AO, Charles P, Maini RN \& Hazleman BL. Autoantibodies in malaria, tuberculosis and hepatitis B in a West African population. Clin Exp Immunol 1993; 92: 7376.

[5] Jakosen PH, Morris-Jones SD, Hviid L, Theander TG, Hoier-Madsen M \& Bayoumi RA. Antiphospholipids antibodies in patients with Plasmodium falciparum malaria. Immunology 1993; 79: 653-657.

[6] Arviex J, Renaudineau Y, Mane I, Perraut R, Krilis SA \&Youinou P. Distinguishing features of anti-beta2 glycoprotein I antibodies between patients with leprosy and the antiphospholipid syndrome. Thromb Haemost 2002; 4: 599-605.

[7] Consigny PH, Cauquelin B, Agnamey P, Comby E, Brasseur $\mathrm{P} \&$ Ballet JJ. High prevalence of co-factor independent anticardiolipin antibodies in malaria exposed individuals. Clin Exp Immunol 2002; 127: 158-164.

[8] Loizou S, Singh S, Wypkema E \& Asherson RA. Anticardiolipin. Anti- $\beta 2$ - glycoprotein 1 and antiprothrombin 
antibodies in black South African patients with infectious disease. Ann Rheum Dis 2003; 62: 1106-1111.

[9] Asheron RA \& Cervera R. Antipospholipid antibodies and infection. Ann Rheum Dis 2003; 26: 388-393.

[10] Ali HA, Osman RR, Idris MN \& Sokrab TO. Anticardiolipin antibodies in stroke patients in Sudan . Neurosciences 2007; Vol. 12 (1): 21-24.

[11] Cervera R \& Asherson RA. Antiphospholipid syndrome associated with infections: clinical and microbiological characteristics. Immunobiology 2005;210: 735-741.

[12] Ordi-Ros J, Villarreal J, Monegal F, Sauleda S, Esteban I \&Vilardell M. Anticardiolipin Antibodies in Patients with Chronic Hepatitis C Virus Infection: Characterization in Relation to Antiphospholipid Syndrome. Clin Diagn Lab Immunol. 2000 March; 7(2): 241-244.

[13] Pybus OG, Drummond AJ, Nakano T, Robertson BH \&Rambaut A. The Epidemiology and Iatrogenic Transmission of HCV in Egypt: A Bayesian Coalescent Approach. Mol Biol Evol 2003; 20 (3) : 381-7.

[14] Global distribution of hepatitis A, B, and C. Weekly epidemiological record 2002;77 (6) :41-8.

[15] Armstrong GL, Wasley A, Simard EP, Mcqillan G, Kuhnert WL \& Alter MJ. The prevalence of hepatitis C virus infection in the United States, 1999 through 2002. Ann Intern Med.2006; 144: 705-14.

[16] World Health Organization and Viral Hepatitis Prevention Board. Global surveillance and control of hepatitis C. J Viral Hepat. 1999; 6: 35-47.

[17] Nguyen TT, Sedghi-Vaziri A \& Wilkes LB. Fluctuations in viral load (HCV RNA) are relatively insignificant in untreated patients with chronic HCV infection. J Viral Hepat. $1996 ; 3: 75-8$.

[18] Seeff LB. Natural history of chronic hepatitis C. Hepatology. $2002 ; 36:$ S35-46

[19] El-Zanaty F \& Way A 2009. Egypt Demographic and Health Survey 2008. Cairo, Egypt: Ministry of Health, El-Zanaty and Associates, and Macro International.

[20] Lunel F\& Cacoub P. Treatment of autoimmune and extrahepatic manifestations of hepatitis $\mathrm{C}$ virus infection. $\mathrm{J}$ Hepatol, 1999; 31(Suppl.1): 210-6.

[21] Trejo O, Ramos-Casals $M$ \& García-Carrasco M. Cryoglobulinemia: Study of etiologic factors and clinical and immunologic features in 443 patients from a single center. Medicine (Baltimore) 2001; 80:252-62.

[22] Mohamed MK. Epidemiology of HCV in Egypt 2004. The Afro-Arab Liver Journal 2004; 3, (2):41-52.

[23] Centers for Disease Control and Prevention. Recommendations for prevention and control of hepatitis $\mathrm{C}$ virus (HVC) infection and HVC-related chronic disease. Morbidity and Mortality Weekly Report. 2003; 47:1-39.

[24] Raja NS\& Janjua KA. Epidemiology of hepatitis C virus infection in Pakistan. J Microbiol Immunol Infect. J Microbiol Immunol Infect 2008, 41:4-8.

[25] Berenguer M, Lopez-Labrador FX \& Wright TL. Hepatitis C and liver transplantation. J Hepatol 2001, 35:666-8.

[26] De Francesco R, Tomei L, Altamura S, Summa V \& Migliaccio G. Approaching a new era for hepatitis $\mathrm{C}$ virus therapy: inhibitors of the NS3-4A serine protease and the NS5B RNA-dependent RNA polymerase. Antiviral Res 2003, 58:1-16.

[27] Beaulieu PL, \& Tsantrizos YS. Inhibitors of the HCV NS5B polymerase: new hope for the treatment of hepatitis $\mathrm{C}$ infections. Curr Opin Investig Drugs 2004, 5:838-850.

[28] Hope RG, Murphy DJ \& McLauchlan J. The domains required to direct core proteins of hepatitis $C$ virus and GB virus-B to lipid droplets share common features with plant oleosin proteins. J Biol Chem 2002, 277:4261-70.

[29] Lerat H, Honda M, Beard MR, Loesch K, Sun J, Yang Y, Okuda M, Gosert R, Xiao SY, Weinman SA \& Lemon SM. Steatosis and liver cancer in transgenic mice expressing the structural and nonstructural proteins of hepatitis $\mathrm{C}$ virus. Gastroenterol 2002, 122:352-65.

[30] Tellinghuisen TL \& Rice CM. Interaction between hepatitis $\mathrm{C}$ virus proteins and host cell factors. Curr Opin Microbiol 2002, 5:419- 427.

[31] Cappellini MD, Musallam KM, Marcon A \& Taher AT. Coagulopathy in Beta Thalassemia Current Understanding Future Perspectives. Medit J Hemat Infect Dis 2009, 1(1):220090.

[32] Tripodi A, Cappellini MD, Chantarangkul V, Padovan L, Fasulo MR, Marcon A \& Mannucci PM. Hypercoagulability in splenectomized thalassemic patients detected by wholeblood thromboelastometry, but not by thrombin generation in platelet-poor plasma. Haematologica 2009;94:1520-1527. 